\title{
New estimate of Sun's distance
}

\section{Pliny Earle Chase LL.D.}

To cite this article: Pliny Earle Chase LL.D. (1879) New estimate of Sun's distance, Philosophical Magazine Series 5, 7:44, 377-377, DOI: 10.1080/14786447908639628

To link to this article: http://dx.doi.org/10.1080/14786447908639628

$$
\text { 曲 Published online: } 13 \text { May } 2009 .
$$

Submit your article to this journal 전

LII Article views: 2

Q View related articles $\asymp$ 


$$
\begin{aligned}
& \text { Thermometer 1. ....... } k=0.0000012179 \\
& " \quad 2 . \ldots \ldots \ldots .0 .0000012245 \\
& " \quad 3 . \ldots \ldots . .600000012360 \\
& \text { Mean .. } \overline{0 \cdot 0000012351}
\end{aligned}
$$

M. Reguault found directly for cold-beaten red copper

$$
k=0.000001317 \text {. }
$$

(4) The diminution of volume varied between much wider limits than $k$. The highest value I bave calculated is $a=0.000865$. Admitting this number, the greatest pressure that could be developed by a deposit of copper on an absolutely resisting cylinder $(m=0)$ would be nearly 300 atmospheres. In reality I have not yet observed pressures above 100 or 110 atmospheres.

I am still pursuing these researches, for which M. Jamin has placed at my disposal all the resources of his laboratory.-Comptes Rendus de l'Académie des Sciences, March 13, 1879, t. lxxxviii. pp. $714-716$.

\section{NEW ESTIMATE OF SUN'S DISTANCE. BY PLINY EARLE CHASE, LL.D.}

In accordance with the principles of my spectral harmonics, Lockyer's fundamental "basic line" (4215 ten-millionths of a.millimetre) gives the following equation :-

$$
\frac{\text { Earth's orbital unit }}{\text { fundamental unit }}=\left(\frac{\odot \text { radius }}{\oplus \text { radius }}\right)^{3} \text {. }
$$

This gives 93,700,000 miles for Sun's distance.

The "orbital unit" is the mean orbital movement of Earth while a body at Earth's equatorial surface falls through the increment of the fundamental line.

Lockyer's "basic lines," Peirce's meteoric hypothesis, and my demonstration of the influence of light in world-building and molecular grouping lead to the equation of mass-

$$
\text { Jupiter }^{3}=\text { Sun } \times \text { Earth } \times \text { Saturn. }
$$

This equation gives the following values:-

$$
\begin{aligned}
\text { Sun's mass } & =328,600, \\
,, \text { distance } & =92,549,000 \text { miles, } \\
,, \text { parallax } & =8^{\prime \prime} \cdot 8322 .
\end{aligned}
$$

Haverford College, Pennsylvania, March 25, 1879 .

Puinx E. Chase.

\section{CONTRIBUTION TO THE THEORY OF THE MICROPHONE. BY HERMANN ARON.}

The microphone is based, as is well known, upon the fact that vibrations produce in it alterations of the resistance, whence axise fluctuations of current which are perceived by means of a telephouc. 